\title{
ARTIKELEN
}

\section{Nieuwe zelfstandigen en onzekerheid over de arbeidsplaats}

\author{
Tinka van Vuuren \& John Klein Hesselink
}

In dit artikel gaan we na of zelfstandigen zonder personeel (zzp'ers) meer arbeidsplaatsonzekerheid ervaren dan werknemers met een vast arbeidscontract. Daarnaast vergelijken we zzp'ers wat betreft de oorzaken en gevolgen van arbeidsplaatsonzekerheid met deze 'reguliere' werknemers. Ook onderzoeken wij of zzp'ers verschillen van vaste werknemers in de mate waarin hun vertrouwen in eigen kunnen (self-efficacy) de negatieve gevolgen van arbeidsplaatsonzekerheid voor welzijns- en gezondheidskenmerken vermindert. Dit doen wij door gebruik te maken van data die verzameld zijn in 2006 in het kader van onderzoek naar aanspraken op de Ziektewet. De analyses in dit artikel zijn gebaseerd op representatieve steekproeven van zzp'ers en werknemers met een arbeidsovereenkomst voor onbepaalde tijd. Het blijkt dat zzp'ers vrijwel evenveel arbeidsplaatsonzekerheid ervaren als vaste werknemers. Wat betreft zowel de oorzaken voor arbeidsplaatsonzekerheid als de reacties hierop zijn er eveneens meer overeenkomsten dan verschillen tussen zzp'ers en werknemers. Hoewel beide groepen negatieve gevolgen ervaren van arbeidsplaatsonzekerheid, gaan vaste werknemers daar iets meer onder gebukt dan zzp'ers. Self-efficacy blijkt noch voor zzp'ers, noch voor vaste werknemers de gevolgen van arbeidsplaatsonzekerheid te verminderen voor het welzijn en de gezondheid.

\section{Inleiding}

Het aantal zelfstandigen zonder personeel (zzp'ers) zit weer in de lift. Door de economische crisis verminderde in de loop van 2009 het aantal zelfstandigen zonder personeel (Kösters \& Dekker, 2010). Sinds begin 2010 is dit aantal weer aan het stijgen. In het derde kwartaal van 2010 telde Nederland 708 duizend zelfstandigen zonder personeel (Kösters, 2010). Bijna één op de tien werkenden in Nederland is een zelfstandige zonder personeel. Volgens de definitie van het CBS is dit iemand met als (hoofd)baan het verrichten van arbeid voor eigen rekening of risico in een eigen bedrijf of praktijk, of in een zelfstandig uitgeoefend beroep en die daarbij geen personeel in dienst heeft. Het CBS: 'Het gaat om ondernemers die geen personeel in dienst hebben. Het kan ook slaan op een freelancer. De zzp'er is zelfstandig in die zin dat hij/zij geen arbeidsovereenkomst heeft, maar wel diensten en/of goederen levert aan klanten of opdrachtgevers. Er is geen sprake van

* Tinka van Vuuren, Open Universiteit Heerlen en Loyalis Consult, Postbus 4946, 6401 HV Heerlen, Tinka.van.Vuuren@Loyalis.nl. John Klein Hesselink, TNO, Postbus 718, 2130 AS Hoofddorp 
een gezagsverhouding, waardoor hij/zij geen werknemer is en niet onder de wettelijke bepalingen voor de werknemer valt' (CBS, 2008).

Er is overigens een verschil tussen de definitie van het CBS en de fiscale definitie. Zo definieert de fiscus bijvoorbeeld ondernemers met een onderneming als zelfstandige rechtspersoon niet als zzp'er. Het CBS beschouwt veel ondernemers met een eigen winkel, agrarische onderneming of professionele praktijk, maar zonder werknemers in dienst wel als zzp'er. In dit artikel sluiten we aan bij de definitie van de fiscus.

Zzp'ers zijn voor werkgevers aantrekkelijke krachten om in te schakelen. Van zzp'ers kunnen werkgevers makkelijker dan van werknemers afscheid nemen als de klus geklaard is. De helft van het Nederlandse bedrijfsleven gebruikt onder meer daarom zzp'ers. Iets minder dan een kwart van de bedrijven die zelfstandigen zonder personeel inhuren, noemt flexibiliteit in de personeelsvoorziening als reden (Taal, 2010).

Zelfstandigen zonder personeel in dienst bieden hun diensten aan op de markt en opdrachtgevers betalen een contractueel met de zzp'er overeengekomen bedrag voor de uitvoering van de dienst (Klein Hesselink et al., 2008). Een zzp'er doet werk dat van oudsher in een dienstbetrekking wordt gedaan. Vaak is dit werk arbeidsintensief van aard, bijvoorbeeld als het gaat om klussen in de bouw, de transportsector, de kappersbranche of de zorgsector of bij het werk van zelfstandig werkende opleiders, interim-managers, organisatieadviseurs en automatiseringsdeskundigen.

Onzekerheid over de arbeidsplaats betreft de bezorgdheid over het toekomstig voortbestaan ervan (Van Vuuren, 1990). Het fenomeen is tot dusver vooral onderzocht bij werknemers. Onzekerheid over de arbeidsplaats treedt echter op bij iedere arbeidsrelatie. Steeds meer mensen werken als uitzendkracht, hebben een tijdelijke aanstelling of werken als zzp'er. Het centrale kenmerk van deze nieuwe flexibele arbeidsrelaties is dat er per definitie meer onzekerheid is over het voortbestaan van het werk (Klein Hesselink \& Van Vuuren, 1999; De Cuyper \& De Witte, 2007; Klandermans et al., 2010). De gevolgen van onzekerheid over het voortbestaan van de arbeidsplaats zijn al uitvoerig onderzocht bij werknemers. Werknemers die bang zijn hun werk te verliezen, zijn minder tevreden over hun baan, voelen zich minder betrokken bij de organisatie, voelen zich minder gezond en denken er meer over om in de nabije toekomst ander werk te zoeken (Van Vuuren, 1991; Hartley et al., 1991; Klandermans \& Van Vuuren, 1999; Sverke et al., 2002; Cheng \& Chan, 2008).

Er is echter maar weinig bekend over arbeidsplaatsonzekerheid bij zzp'ers en de mate waarin zij daarin verschillen van werknemers met een arbeidsovereenkomst voor onbepaalde tijd. In het artikel gaan we in op de vraag of zzp'ers in de mate, oorzaken en gevolgen van arbeidsplaatsonzekerheid verschillen van vaste werknemers. 


\section{Definitie van arbeidsplaatsonzekerheid}

In dit artikel wordt met arbeidsplaatsonzekerheid een bezorgdheid over het voortbestaan van de arbeidsplaats bedoeld (Van Vuuren, 1990; Greenhalgh \& Rosenblatt, 1984). In het geval van vaste werknemers is de arbeidsplaats hun baan. Zzp'ers hebben echter geen baan. Zij verrichten in het kader van hun bedrijf, werkzaamheden voor eigen rekening en risico op contractbasis, maar zonder arbeidscontract (Dekker \& Kösters, 2010). Bij zzp'ers verstaan wij daarom onder hun arbeidsplaats hun bedrijf.

Arbeidsplaats(on)zekerheid valt te onderscheiden van andere vormen van (on)zekerheid. Zo maakt de literatuur onderscheid tussen baanzekerheid, werkzekerheid, inkomenszekerheid en sociale zekerheid (Wilthagen \& Tros, 2004; Dekker \& Kösters, 2010). Zelfstandigen hebben geen baanzekerheid in tegenstelling tot werknemers, want ze hebben geen baan, maar kunnen dus wel (on)zeker zijn over het behoud van hun bedrijf als arbeidplaats. Dekker en Kösters (2010: 7) stellen dat de werkzekerheid, dat wil zeggen de (on)zekerheid over het behouden, vinden en creëren van betaald werk nu en in de toekomst, van zzp'ers niet noodzakelijk lager hoeft te zijn dan van vaste werknemers, maar wel hun inkomenszekerheid en sociale zekerheid. Onzekerheid over de arbeidsplaats heeft drie kenmerken (Van Vuuren, 1990). Ten eerste is het een subjectieve ervaring. De zzp'er kan zich zorgen maken over het behoud van zijn of haar bedrijf, hoewel er objectief gezien geen reden voor hoeft te zijn. Ten tweede heeft de onzekerheid over de arbeidplaats betrekking op de toekomst. Op dit moment heeft de zzp'er wel een bedrijf en is er alleen geen duidelijkheid of het bedrijf standhoudt in de toekomst. Ten derde gaat de onzekerheid over de arbeidsplaats bij zzp'ers over het behoud van het bedrijf (ook wel kwantitatieve onzekerheid genoemd) en niet over de inhoud van het bedrijf (kwalitatieve onzekerheid; Hellgren, Sverke \& Isaksson, 1999). Onzekerheid over de arbeidsplaats betreft voor zzp'ers de mogelijkheid het bedrijf te verliezen en is dus meer dan alleen onzekerheid over het voortbestaan van kenmerken van het bedrijf, bijvoorbeeld een ander inkomen, locatie of aard van de werkzaamheden.

De mate van arbeidsplaatsonzekerheid zien wij als een functie van de kans op het verlies van de arbeidsplaats en van de ernst van de gevolgen van het verlies daarvan (Van Vuuren, 1990; Klandermans, Van Vuuren \& Jacobson,1991; Klandermans et al., 2010). Volgens Klandermans et al. (1991) zijn beide aspecten even belangrijk bij het zich zorgen maken over het voortbestaan van de arbeidsplaats. Dat betekent dat hoe waarschijnlijker de mogelijkheid om de arbeidsplaats te verliezen en hoe ernstiger de gevolgen van het verliezen van de arbeidsplaats, hoe meer onzekerheid men ervaart over het voortbestaan van de arbeidsplaats. Jacobson (1985) gaat zelfs verder en stelt dat alleen wanneer iemand denkt dat hij zowel een kans maakt om de arbeidsplaats te verliezen als de gevolgen van het verlies ernstig vindt, hij onzekerheid over de arbeidsplaats zal ervaren.

Ook Sverke et al. (2002) bevelen aan om arbeidsplaatsonzekerheid te onderzoeken via een multidimensioneel instrument en zich niet alleen te beperken tot een operationalisatie van de kans op verlies van de arbeidsplaats, maar ook de mate van bezorgdheid mee te nemen in de operationalisatie. Sverke et al. (2002) verwij- 
zen hiermee naar het onderscheid tussen cognitieve en affectieve arbeidsplaatsonzekerheid. Cognitieve arbeidsplaatsonzekerheid betreft de gepercipieerde ingeschatte kans van verlies van de arbeidsplaats. Terwijl affectieve arbeidsplaatsonzekerheid betrekking heeft op de subjectieve gevoelsmatige beleving: zich onzeker voelen, bezorgd zijn over het mogelijke verlies van de arbeidsplaats (Hartley et al., 1991; De Witte, 2000; Handaja \& De Witte, 2008).

In deze studie definiëren wij arbeidsplaatsonzekerheid als de bezorgdheid over het mogelijke baanverlies (affectieve arbeidsplaatsonzekerheid). Deze affectieve arbeidsplaatsonzekerheid is is op haar beurt weer afhankelijk van de kans op verlies (cognitieve arbeidsplaatsonzekerheid) en de ervaren ernst van de gevolgen van het verlies van de arbeidsplaats (Van Vuuren, 1990; Klandermans, Van Vuuren \& Jacobson,1991). De samenhang met de kans op het verlies van de arbeidsplaats en de ernst van de eventuele gevolgen van dit verlies onderzoeken wij in tegenstelling tot veel onderzoek op dit gebied apart. Wij doen dat omdat wij veronderstellen dat juist het ontbreken van dit onderscheid ertoe heeft geleid dat er inconsistente uitkomsten zijn gevonden in het onderzoek naar de gevolgen van onzekerheid over de arbeidsplaats bij flexibele arbeidskrachten. De Cuyper en De Witte (2008) vinden namelijk dat tijdelijke arbeidskrachten wel meer arbeidsplaatsonzekerheid ervaren, maar daar minder negatieve gevolgen van ervaren dan vaste krachten. In een volgende paragraaf gaan wij verder in op deze resultaten.

\section{Determinanten van arbeidsplaatsonzekerheid}

Personen in dezelfde situatie verschillen in de mate van onzekerheid die zij ervaren. Dit komt doordat de beleefde onzekerheid afhankelijk is van de kans die zij denken te hebben op verlies van de arbeidsplaats en de ernst die zij vrezen van de gevolgen (Van Vuuren, 1990; Klandermans, Van Vuuren \& Jacobson, 1991). Factoren die één van deze twee dimensies beïnvloeden, hebben dus ook gevolgen voor de gevoelens van onzekerheid over de arbeidsplaats. De Witte (2005) beschrijft in zijn overzichtsartikel over antecedenten en gevolgen van arbeidsplaatsonzekerheid factoren op macroniveau zoals de economie, kenmerken van een regio of van een organisatie waardoor personen vrezen dat zij het risico lopen om hun werk te verliezen. Daarnaast wijst hij op individuele kenmerken zoals leeftijd, nationaliteit, geslacht, lengte van het dienstverband en dergelijke die de kans kunnen vergroten dat iemand zijn of haar arbeidsplaats verliest. Vooral de aard van de arbeidsrelatie blijkt van belang te zijn. Werknemers met een tijdelijk contract ervaren meer onzekerheid over hun arbeidsplaats dan werknemers met een vast contract (De Cuyper \& De Witte, 2005, 2006, 2007, 2008; Klandermans et al., 2010; Klein Hesselink \& Van Vuuren, 1999; Parker, Griffin, Sprigg \& Wall, 2002; Pearce, 1998.) Dit is goed te verklaren. Mensen met een tijdelijke baan verliezen ook daadwerkelijk vaker hun arbeidsplaats dan de werknemers met een vaste baan. Een studie van het UWV (Hilbers, 2010) wijst uit dat Nederlandse flexwerkers vier keer zo vaak de WW instromen als werknemers in vaste dienst. Klandermans et al. (2010) vinden dan ook dat flexwerkers zoals uitzendkrachten en tijdelijke werknemers menen dat zij een grotere kans op ontslag hebben dan 
vaste werknemers. Daarentegen blijken flexwerkers minder ernstige gevolgen te verwachten van het verlies van hun arbeidsplaats dan personen met een vaste baan (Klandermans et al., 2010).

Daarnaast hangt onzekerheid over de arbeidsplaats samen met bepaalde persoonlijkheidskenmerken. Bijvoorbeeld hoe sterker de externe beheersingsoriëntatie, hoe lager de zelfwaardering, hoe pessimistischer en/of neurotischer men is, des te meer arbeidsplaatsonzekerheid men ervaart (De Witte, 2005; Kinnunen, Feldt \& Mauno, 2003; Sverke et al., 2004; Van Vuuren, 1990; Klandermans \& Van Vuuren, 1991). Ook de mate waarin iemand beschikt over 'self-efficacy' - het vermogen en de overtuiging om adequaat en efficiënt te handelen in een gegeven situatie (Bandura, 1997; Bandura, 1998) - lijkt van belang te zijn. Ashford, Lee en Bobko (1989) vinden dat persoonlijke kenmerken en werksituaties die wijzen op een waargenomen gebrek aan controle samengaan met meer ervaren arbeidsplaatsonzekerheid. Self-efficacy blijkt inderdaad te correleren met minder gevoelens van arbeidsplaatsonzekerheid (König et al., 2010; Scheurs et al., 2010), maar niet in alle onderzoeken (Sverke et al., 2004).

In dit onderzoek nemen we de volgende determinanten mee, omdat we verwachten dat deze samenhangen met de mate waarin de werknemers en zzp'ers vrezen hun arbeidsplaats te verliezen: leeftijd, self-efficacy, persoonlijke ontwikkelingsmogelijkheden, groeimogelijkheden binnen of buiten het eigen bedrijf of eigen branche of bedrijf en groeigedrag (uitbreiden van bedrijf of solliciteren naar andere baan).

Daarnaast onderzoeken we de volgende determinanten omdat we verwachten dat deze samenhangen met de mate waarin werknemers en zzp'ers vrezen dat het verlies van hun arbeidsplaats ernstige gevolgen heeft: geslacht, burgerlijke staat, zorg voor kinderen, opleidingsniveau, persoonlijk en huishoudinkomen, aantal werkuren per week en de kans op nieuw werk.

\section{Gevolgen van arbeidsplaatsonzekerheid}

Arbeidsplaatsonzekerheid heeft ernstige gevolgen voor werknemers. Zij zijn minder tevreden met hun werk, minder betrokken bij de organisatie, voelen zich minder gezond en denken meer de organisatie te verlaten als zij zich zorgen maken over het behoud van hun baan (Van Vuuren, 1990; Van Vuuren, 1991; Van Vuuren et al., 1991b; Hartley et al., 1991; Klandermans \& Van Vuuren, 1999; Sverke, Hellgren \& Näswall, 2002; Kinnunen \& Nätti, 1994; De Cuyper \& De Witte, 2006; Cheng \& Chan, 2008). De vraag is of dit ook geldt voor zzp'ers. Flexibele arbeidskrachten die meer arbeidsplaatsonzekerheid ervaren dan vaste krachten, lijken namelijk minder gebukt te gaan onder de gevolgen van arbeidsplaatsonzekerheid dan deze vaste krachten (De Witte \& Näswall; 2003; De Cuyper \& De Witte, 2006, 2007, 2008). Een mogelijke verklaring voor de verschillen in de gevolgen van arbeidsplaatsonzekerheid tussen flexibele en vaste krachten is dat tot nu toe nauwelijks onderscheid wordt gemaakt tussen beide dimensies van arbeidsonzekerheid: de waargenomen kans op het verlies van de arbeidsplaats en de ervaren ernst van de gevolgen daarvan. Klandermans et al. (2010) vinden dat flexibele 
arbeidskrachten meestal inschatten dat hun kans om het werk te verliezen groot is, maar dat de gevolgen daarvan vaak niet zo ernstig zijn. Dit in tegenstelling tot vaste krachten die de kans op verlies van werk als laag inschatten, maar de ernst van de gevolgen als hoog. Dit verklaart waarom bij vaste arbeidskrachten een kleine toename in de kans om het werk te verliezen, grote gevolgen heeft, terwijl eenzelfde kleine toename bij flexibele arbeidskrachten er niet toe doet, omdat zij toch al een grote kans ervaren om het werk te verliezen.

In dit artikel onderzoeken we in navolging van Sverke et al. (2002) en Cheng en Chan (2008) de gevolgen voor de houding ten opzichte van werk en de gevolgen voor de gezondheid. Zij maakten namelijk in twee grote meta-analyses over arbeidsplaatsonzekerheid bij werknemers onderscheid wat betreft de individuele gevolgen tussen de directe reacties voor de houding ten opzichte van het werk en de reacties op langere termijn voor de gezondheid (Sverke et al., 2002; Cheng \& Chan, 2008). Wij doen dit aan de hand van de volgende welzijns- en gezondheidskenmerken: tevredenheid met het werk, mate waarin men meent dat het functioneren thuis wordt belemmerd door het werk (werk-thuis interferentie, Geurts \& Demerouti, 2003), gezondheid, ondanks ziekte toch doorwerken (presenteïsme, zie Johns, 2010) en ziekteverzuim.

\section{Self-efficacy als moderator?}

Het gaat hier om de vraag hoe de factor self-efficacy (vertrouwen in eigen kunnen) de relatie tussen arbeidsplaatsonzekerheid en de gevolgen daarvan in termen van welbevinden en gezondheid beïnvloedt. Een belangrijk kenmerk van zzp'ers is namelijk dat zij meer vertrouwen hebben in eigen kunnen dan werknemers en dat zij daardoor de risico's van zelfstandig ondernemerschap beter zouden aankunnen (McKeown, Connelly \& Gallagher, 2009). Volgens Baron en Kenny (1986) is een moderatorvariabele een kwalitatieve (bijvoorbeeld geslacht, ras of sociale klasse) of kwantitatieve variabele (bijvoorbeeld beloning) die van invloed is op de richting en/of de sterkte van een relatie tussen een onafhankelijke of voorspellende variabele en de afhankelijke of criteriumvariabele. Een moderator is volgens deze auteurs dus anders dan een mediatorvariabele, die een tussenliggende schakel is tussen de voorspellende en de criteriumvariabele.

Het vermogen en de overtuiging om adequaat en efficiënt te handelen in een gegeven situatie (self-efficacy) bepaalt volgens Bandura (1997; 1998) de mate waarin men zich in wil zetten en hoe lang men wil doorgaan als men te maken heeft met allerlei stressvolle situaties. Bandura (1997) laat zien dat in het algemeen geldt: hoe groter iemands self-efficacy, hoe beter iemands gezondheid en welbevinden. Daarnaast veronderstelt Bandura (1998) dat in geval men controle ervaart over een stressvolle situatie, deze niet zal leiden tot een stressreactie. Vertaald naar een situatie van arbeidsplaatsonzekerheid zou dit betekenen dat personen met een grotere mate van self-efficacy beter om kunnen gaan met gevoelens van arbeidsplaatsonzekerheid, waardoor hun welbevinden en gezondheid minder worden geschaad. Self-efficacy zou dus een bufferende werking kunnen hebben. 
Zo onderzoeken Schreurs et al. (2010) self-efficacy als een mogelijke factor die de negatieve gevolgen van arbeidsplaatsonzekerheid vermindert.

Tot nu toe is het onderzoek naar de bufferende werking van self-efficacy op de gevolgen van arbeidsplaatsonzekerheid vooral gedaan bij werknemers. Wij veronderstellen dat het optreden van dit moderatoreffect afhankelijk is van de mate waarin men daadwerkelijk de stressvolle situatie kan beïnvloeden. Dit zou voor vaste werknemers en zzp'ers kunnen verschillen. Werknemers zijn minder in staat om deze stressvolle situatie daadwerkelijk te beïnvloeden. Vaste werknemers hebben minder invloed op het behoud van hun baan dan zzp'ers op het behoud van hun onderneming.

Bovendien is te verwachten dat de mate van self-efficacy sterker is bij zzp'ers dan bij werknemers met een vaste baan (McKeown et al., 2009). Zo staat zelfvertrouwen als eerste persoonlijkheidskenmerk genoemd op een lijst van de tien persoonlijkheidskenmerken van 'effectieve' zzp'ers (Camden, 2008). Ook Daselaar (2011) en Van den Boomen (2011) schrijven in hun praktijkhandboeken voor de zzp'ers dat zzp'ers een sterk vertrouwen dienen te hebben in de eigen capaciteiten.

De onderzoeksvragen in dit artikel luiden:

1. Verschillen zzp'ers van werknemers met een vast dienstverband in arbeidsplaatsonzekerheid?

2. Verschillen zzp'ers van werknemers met een vast dienstverband in de determinanten van en reacties op arbeidsplaatsonzekerheid?

3. Verschillen zzp'ers van werknemers als het gaat om de bufferende werking van self-efficacy op de negatieve gevolgen van arbeidsplaatsonzekerheid?

\section{Data}

In het onderzoek van Klein Hesselink et al. (2008) is in verband met Ziektewetaanspraken nagegaan of werknemers met een tijdelijke aanstelling op het moment dat ze geen werkgever meer hebben een ander verzuimpatroon hebben dan werknemers met een vaste aanstelling. Omdat een kwart van de zzp'ers ook aanspraak kan maken op een Ziektewetuitkering, is deze groep ook onderzocht en vergeleken met ondernemers. Daarbij is niet alleen gekeken naar de verzuimpatronen, maar ook naar de achtergronden van het verzuim. De analyses in dit artikel zijn gebaseerd op de steekproeven van zzp'ers en werknemers met een vaste aanstelling uit dit onderzoek.

Het vragenlijstonderzoek is in november 2006 uitgevoerd in twee fasen. De eerste fase bestond uit een screening onder alle respondenten van 18 jaar en ouder uit het online panel van Intomart GFK. Op basis daarvan is in de tweede fase een internetenquête gehouden onder een gestratificeerde selectie respondenten uit dit panel. In totaal hebben 72.805 respondenten van 18 tot en met 64 jaar de vragen van de screening-vragenlijst ingevuld. De samenstelling van dit bestand is representatief voor de Nederlandse populatie van werkenden in 2006. Bij alle respondenten is tijdens de screening de arbeidssituatie vastgesteld. Zelfstandigen konden de categorie 'Zelfstandige met of zonder personeel' aankruisen. Ze werden doorgeleid naar de vraag 'Op welke wijze werkt u als zelfstandige?' De vier 
antwoordcategorieën waren: (1) Zzp'er (= zelfstandige zonder personeel), freelancer, franchisenemer of aannemer van werk op persoonlijke titel, (2) Zelfstandige/ firmant en werkzaam in een eigen onderneming, (3) Zelfstandige als meewerkend gezinslid en (4) Weet niet. Werknemers met een vaste baan konden de categorie 'Een vaste aanstelling (geen oproepcontract)' aankruisen.

In de tweede fase is een internetenquête gehouden onder een gestratificeerde steekproef van 2011 respondenten uit de totale groep. Stratificatie vond plaats op basis van elf arbeidscontractsituaties. Per contractsituatie zijn de respondenten at random gekozen waardoor de elf groepen representatief zijn voor de populatie van iedere groep. Voor de analyses in dit artikel is de netto steekproef van 251 personen die hadden aangegeven te behoren tot de categorie 'zzp'er, freelancer, franchisenemer of aannemer van werk op persoonlijke titel' vergeleken met de netto steekproef van 502 werknemers met een vaste aanstelling. Beide groepen kregen een eigen variant van de vragenlijst aangeboden, waarbij alleen de vragen over de arbeidssituatie verschilden. Bij zelfstandigen gingen de vragen over de zakelijke activiteiten en de opdrachtgevers/klanten daarbij. Bij werknemers gingen de vragen over de relatie tussen werknemer en werkgever. Voor de overige vragen zijn in de beide varianten van de vragenlijst exact dezelfde vragen gesteld. De oorspronkelijke twee vragenlijsten bestonden uit ruim 100 variabelen. Voor de analyses in dit artikel is een selectie daarvan onderzocht. De volgende twee vragen meten de arbeidsplaatsonzekerheid:

De kans op het verlies van de arbeidsplaats is gemeten door de zzp'ers de volgende vraag te stellen: 'Hoe groot acht $\mathrm{u}$ de kans dat $\mathrm{u} u \mathrm{u}$ huidige bedrijf verliest? Acht $\mathrm{u}$ die kans zeer groot $(1)$, groot $(0,75)$, redelijk $(0,5)$, klein $(0,25)$ of zeer klein $(0)$ ?' Aan de groep werknemers met een vast dienstverband is gevraagd: 'Hoe groot acht $\mathrm{u}$ de kans dat $\mathrm{u}$ uw huidige baan verliest? Acht $\mathrm{u}$ die kans zeer groot (1), groot $(0,75)$, redelijk $(0,5)$, klein $(0,25)$ of zeer klein $(0)$ ?'

De ernst van het verlies van de arbeidsplaats is gemeten door aan de zzp'ers de vraag te stellen: 'Hoe ernstig is het voor $\mathrm{u}$, als $\mathrm{u}$ uw huidige bedrijf verliest? Is dat voor $\mathrm{u}$ zeer ernstig (1), ernstig $(0,75)$, vervelend, maar geen drama $(0,5)$, niet ernstig $(0,25)$ of maakt het u niets uit $(0)$ ?' Aan de groep werknemers met een vast dienstverband is gevraagd: 'Hoe ernstig is het voor $\mathrm{u}$, als $\mathrm{u}$ uw huidige baan verliest? Is dat voor u zeer ernstig (1), ernstig $(0,75)$, vervelend, maar geen drama $(0,5)$, niet ernstig $(0,25)$ of maakt het u niets uit $(0)$ ?'

De volgende determinanten van arbeidsplaatsonzekerheid zijn gebruikt:

1. Geslacht $(0=$ man, $1=$ vrouw $)$;

2. Leeftijd (in jaren tussen 18 en 65);

3. Gehuwd/samenwonend ( 0 = niet, $1=$ wel);

4. Kinderen thuis $(0=$ niet, $1=$ wel $)$;

5. Opleidingsniveau ( $0=$ geen opleiding gevolgd/afgemaakt; $0,14=$ basisonderwijs; 0,29 = mavo; 0,43 = voorbereidend beroepsonderwijs; 0,57 = havo/vwo; $0,71=$ middelbaar beroepsonderwijs; 0,86 = hoger beroepsonderwijs; 1 = wetenschappelijk onderwijs);

6. Maandelijks persoonlijk netto inkomen $(0=$ onder de $€ 500 ; 0,2=€ 500$ tot $€ 1000 ; 0,4=€ 1000$ tot $€ 1500 ; 0,6=€ 1500$ tot $€ 2000 ; 0,8=€ 2000$ tot $€ 2500 ; 1$ = meer dan $€ 2500$ ); 
7. Maandelijks netto huishoudinkomen (inclusief eigen inkomen) ( $0=$ onder de $€ 500 ; 0,2=€ 500$ tot $€ 1000 ; 0,4=€ 1000$ tot $€ 1500 ; 0,6=€ 1500$ tot $€ 2000 ; 0,8=€ 2000$ tot $€ 2500 ; 1=$ meer dan $€ 2500$ );

8. Omvang werkweek: 'Hoeveel uren werkt u gemiddeld per week?' (uren).

9. Persoonlijke ontwikkelingsmogelijkheden is bij de zzp'ers gemeten aan de hand van de vraag: 'Kunt u zich als persoon in uw bedrijf voldoende ontplooien?' Ja (1), Nee (0). Aan de werknemers met een vast dienstverband is gevraagd: 'Heeft uw bedrijf $\mathrm{u}$ (in het afgelopen jaar) opleidingsmogelijkheden aangeboden, zodat u zich in uw vak/beroep kunt ontwikkelen?' Ja (1), Nee (0).

10. Groeimogelijkheden binnen de branche. Aan zzp'ers is gevraagd: 'Zijn er voldoende groeimogelijkheden voor uw organisatie binnen de branche?' ( $0=$ nee, $1=\mathrm{ja}$ ). Aan werknemers is gevraagd: 'Biedt uw huidige baan momenteel voldoende carrièremogelijkheden binnen uw bedrijf?' ( 0 = nee, 1 = ja).

11. Groeimogelijkheden buiten de branche. Aan zzp'ers is gevraagd: 'Zijn er voldoende groeimogelijkheden voor uw organisatie buiten de branche?' ( 0 = nee, 1 = ja). Aan werknemers is gevraagd: 'Biedt uw huidige baan momenteel voldoende carrièremogelijkheden buiten uw bedrijf?' ( 0 = nee, $1=\mathrm{ja}$ ).

12. Groeigedrag. Aan zzp'ers is gevraagd: 'Heeft u in de afgelopen drie maanden pogingen gedaan uw bedrijf uit te breiden?' $(0=$ nee, $1=$ ja $)$. Aan werknemers is gevraagd: 'Heeft $\mathrm{u}$ in de afgelopen drie maanden gesolliciteerd naar een andere baan of functie?' ( 0 = nee, 1 = ja).

13. Kans op nieuwe arbeidsplaats. Aan zzp'ers is gevraagd: 'Hoe groot acht $\mathrm{u}$ de kans dat $\mathrm{u}$ in het geval van het verlies van uw bedrijf, een ander bedrijf gaat oprichten? Acht u die kans zeer groot $(0)$, groot $(0,25)$, redelijk $(0,5)$, klein $(0,75)$ of zeer klein (1)?' Aan werknemers is gevraagd: 'Hoe groot acht u de kans dat $\mathrm{u}$ in het geval van het verlies van uw baan, ander werk zult vinden? Acht u die kans zeer groot $(0)$, groot $(0,25)$, redelijk $(0,5)$, klein $(0,75)$ of zeer klein (1)?'

14. Self-efficacy is gemeten met negen items van de schaal van Schwarzer \& Jeruzalem (1995). Voorbeelden van deze items zijn: 'Het lukt me altijd moeilijke problemen op te lossen, als ik er genoeg moeite voor doe', 'Het is voor mij makkelijk om vast te houden aan mijn plannen en mijn doel te bereiken' en 'Dankzij mijn vindingrijkheid weet ik hoe ik in onvoorziene situaties moet handelen'. De antwoordcategorieën zijn: volledig onjuist (0), nauwelijks juist $(0,33)$, enigszins juist $(0,66)$ en volledig juist (1). Cronbachs alpha is 0,86 .

De volgende mogelijke gevolgen van arbeidsplaatsonzekerheid zijn gemeten:

1. Ziekteverzuimpercentage is berekend op basis van de vragen: 'Heeft $\mathrm{u}$ de afgelopen 12 maanden wel eens verzuimd?', (indien ja) en 'Hoeveel werkdagen heeft $\mathrm{u}$, alles bij elkaar, de afgelopen 12 maanden naar schatting verzuimd?' (Van den Bossche et al., 2007). Het berekende ziekteverzuimpercentage is gecorrigeerd voor in deeltijd werken.

2. Presenteïsmepercentage is gemeten door te vragen: 'Hoeveel dagen heeft $\mathrm{u}$ in de afgelopen drie maanden ziek doorgewerkt?' (Van den Bossche et al., 2007). Het berekende presenteïsmepercentage is gecorrigeerd voor in deeltijd werken. 
3. Ervaren gezondheid is gemeten via de vraag (Smulders, Andries \& Otten, 2001): 'Wat vindt u, over het algemeen genomen, van uw gezondheid?' ( 1 = uitstekend, 0,75 = zeer goed, 0,5 = goed, 0,25 = matig, 0 = slecht.

4. Werk-thuis interferentie is gemeten door twee vragen die gecombineerd zijn tot één variabele (Van den Bossche et al., 2007): 'Hoe vaak komt het voor dat $\mathrm{u}$ moeilijk aan uw taken thuis kunt voldoen omdat $\mathrm{u}$ het te druk heeft op uw werk?' en 'Hoe vaak komt het voor dat u moeilijk uw aandacht bij uw taken thuis kunt houden, omdat u zich druk maakt over zaken op uw werk?' $(0=$ nooit, $0,33=$ soms, $0,66=$ regelmatig, $1=$ vaak $)$. De Pearson-correlatie tussen de twee vragen is 0,45 .

5. Werktevredenheid is gevraagd door Gründemann et al. (1993): 'In hoeverre bent $\mathrm{u}$, alles bij elkaar genomen, tevreden met uw werk?' ( 0 = zeer ontevreden, $0,25=$ ontevreden, $0,5=$ niet ontevreden/niet tevreden, 0,75 = tevreden, 1 = zeer tevreden.

\section{Analysemethodiek en resultaten}

De analyses vonden plaats met behulp van SPSS. Er zijn t-tests, regressieanalyses en meervoudige variantieanalyses uitgevoerd. De meervoudige variantieanalyses zijn afzonderlijk uitgevoerd voor de kans op en de ernst van het verlies van de arbeidsplaats. De aantallen zzp'ers en de spreiding over de onafhankelijke variabelen lieten niet toe om deze verbanden in één analyse te toetsen. Voor het beoordelen van het kansniveau wordt bij de t-test en de regressieanalyses het $5 \%$-niveau aangehouden $(\mathrm{p}<0,05)$ en voor de 3-weg variantieanalyses is het $10 \%$-niveau gehanteerd $(\mathrm{p}<0,10)$.

\section{Verschillen tussen zzp'ers en werknemers met een vast dienstverband}

Tabel 1 vergelijkt de verschillen in arbeidsplaatsonzekerheid en de determinanten en gevolgen daarvan tussen zzp'ers en werknemers met een vast dienstverband. Bij de twee kenmerken van arbeidsplaatsonzekerheid blijkt dat zzp'ers gemiddeld een iets grotere kans waarnemen op verlies van hun arbeidsplaats dan werknemers. In beide groepen wordt de kans echter als klein waargenomen. Wel vinden zzp'ers het even erg om hun arbeidsplaats te verliezen als werknemers. Beide groepen schatten gemiddeld in dat de ernst hiervan ligt tussen 'ernstig' en 'vervelend, maar geen drama'.

Wat betreft de eerste groep determinanten zijn er in tabel 1 geen verschillen tussen zzp'ers en werknemers wat betreft geslacht, samenwonen met een partner, kinderen thuis, het persoonlijke inkomen en het huishoudinkomen. Wel verschillen zzp'ers van werknemers qua leeftijd, opleidingsniveau en aantal werkuren per week. Het gemiddelde van 33,7 werkuren per week laat zien dat ook een deel van de zzp'ers parttime werkt. 
Tabel 1 Verschillen in arbeidsplaatsonzekerheid en de determinanten en gevolgen daarvan bij zzp'ers en werknemers met een vast dienstverband

\begin{tabular}{|c|c|c|c|c|c|}
\hline & & Zzp'ers & $\begin{array}{l}\text { Werk- } \\
\text { nemers }\end{array}$ & Totaal & $\mathbf{p}$ \\
\hline \multicolumn{6}{|c|}{ Arbeidsplaatsonzekerheid } \\
\hline- & Kans op verlies arbeidsplaats groot (range $0-I$ ) & 0,23 & 0,20 & 0,21 & 0,042 \\
\hline- & Verlies arbeidsplaats is ernstig (range $0-I$ ) & 0,62 & 0,65 & 0,64 & 0,162 \\
\hline \multicolumn{6}{|c|}{ Determinanten } \\
\hline- & Geslacht (percentage vrouwen) & $50 \%$ & $53 \%$ & $52 \%$ & 0,381 \\
\hline- & Leeftijd (in jaren) & 41 & 39 & 40 & 0,048 \\
\hline- & Gehuwd/samenwonend (percentage ja) & $76 \%$ & $75 \%$ & $75 \%$ & 0,812 \\
\hline- & Kinderen thuis (percentage ja) & $48 \%$ & $50 \%$ & $50 \%$ & 0,503 \\
\hline- & Opleidingsniveau (range $0-I$ ) & 0,67 & 0,58 & 0,61 & 0,000 \\
\hline- & $\begin{array}{l}\text { Maandelijks persoonlijk netto inkomen (range } \\
0-I \text { ) }\end{array}$ & 0,45 & 0,44 & 0,45 & 0,884 \\
\hline- & Maandelijks netto huishoudinkomen (range $0-I$ ) & 0,64 & 0,66 & 0,66 & 0,190 \\
\hline- & Omvang werkweek (uren) & 33,7 & 31,2 & 32,1 & 0,015 \\
\hline- & $\begin{array}{l}\text { Persoonlijke ontwikkelingsmogelijkheden (per- } \\
\text { centage ja) }\end{array}$ & $87 \%$ & $61 \%$ & $70 \%$ & 0,000 \\
\hline- & $\begin{array}{l}\text { Groeimogelijkheden binnen de branche (per- } \\
\text { centage ja) }\end{array}$ & $84 \%$ & $49 \%$ & $60 \%$ & 0,000 \\
\hline- & $\begin{array}{l}\text { Groeimogelijkheden buiten de branche (per- } \\
\text { centage ja) }\end{array}$ & $66 \%$ & $40 \%$ & $49 \%$ & 0,000 \\
\hline- & Groeigedrag (percentage ja) & $41 \%$ & $19 \%$ & $26 \%$ & 0,000 \\
\hline- & Kans op nieuwe arbeidsplaats klein (range $0-I$ ) & 0,40 & 0,40 & 0,40 & 0,877 \\
\hline- & Self-efficacy (range 0-I) & 0,53 & 0,44 & 0,47 & 0,020 \\
\hline \multicolumn{6}{|c|}{ Gevolgen } \\
\hline- & Verzuimpercentage (deeltijdgecorrigeerd) & $3,7 \%$ & $5,4 \%$ & $4,8 \%$ & 0,129 \\
\hline- & Presenteïsmepercentage (deeltijdgecorrigeerd) & $6,7 \%$ & $5,6 \%$ & $6,0 \%$ & 0,319 \\
\hline- & Ervaren gezondheid goed (range $0-I$ ) & 0,61 & 0,61 & 0,61 & 0,830 \\
\hline- & Werk-thuis interferentie (range $0-I$ ) & 0,35 & 0,29 & 0,31 & 0,000 \\
\hline- & Werktevredenheid (range 0-I) & 0,77 & 0,72 & 0,74 & 0,001 \\
\hline & aal aantal respondenten & 251 & 502 & 753 & - \\
\hline
\end{tabular}

De tweede groep determinanten in tabel 1 laat zien dat de zzp'ers positiever zijn over hun persoonlijke ontplooiingsmogelijkheden dan vaste werknemers. Daarnaast zien de zzp'ers beduidend meer groeimogelijkheden binnen en buiten hun branche dan werknemers binnen en buiten hun eigen bedrijf. Ook ondernemen zzp'ers meer pogingen om hun bedrijf uit te breiden dan werknemers solliciteren naar een andere baan of functie (groeigedrag). Zzp'ers schatten echter de kans op 
nieuw werk even groot in als werknemers. In vergelijking met werknemers hebben zzp'ers wel meer vertrouwen in eigen kunnen (self-efficacy).

Tabel 1 vergelijkt ten slotte zzp'ers en vaste werknemers wat betreft welbevinden en gezondheid. Zzp'ers verschillen niet van werknemers als het gaat om het ziekteverzuimpercentage, het presenteïsmepercentage en ervaren gezondheid. Wel kunnen zzp'ers vaker dan werknemers moeilijk aan de taken thuis voldoen en/of hun aandacht bij de taken thuis houden (werk-thuis interferentie) en zijn ze gemiddeld meer tevreden met hun werk.

\section{Determinanten van onzekerheid over de arbeidsplaats}

Met regressieanalyse is nagegaan in hoeverre arbeidsplaatsonzekerheid (de waargenomen kans op het verlies van het bedrijf of de baan en de ervaren ernst van dit verlies) voorspeld kan worden bij zzp'ers en bij werknemers met een vast dienstverband afzonderlijk (zie tabel 2).

Tabel 2 Regressieanalyse bij zzp'ers en werknemers met als afhankelijke variabelen: de ervaren kans op en ernst van verlies van de arbeidsplaats *)

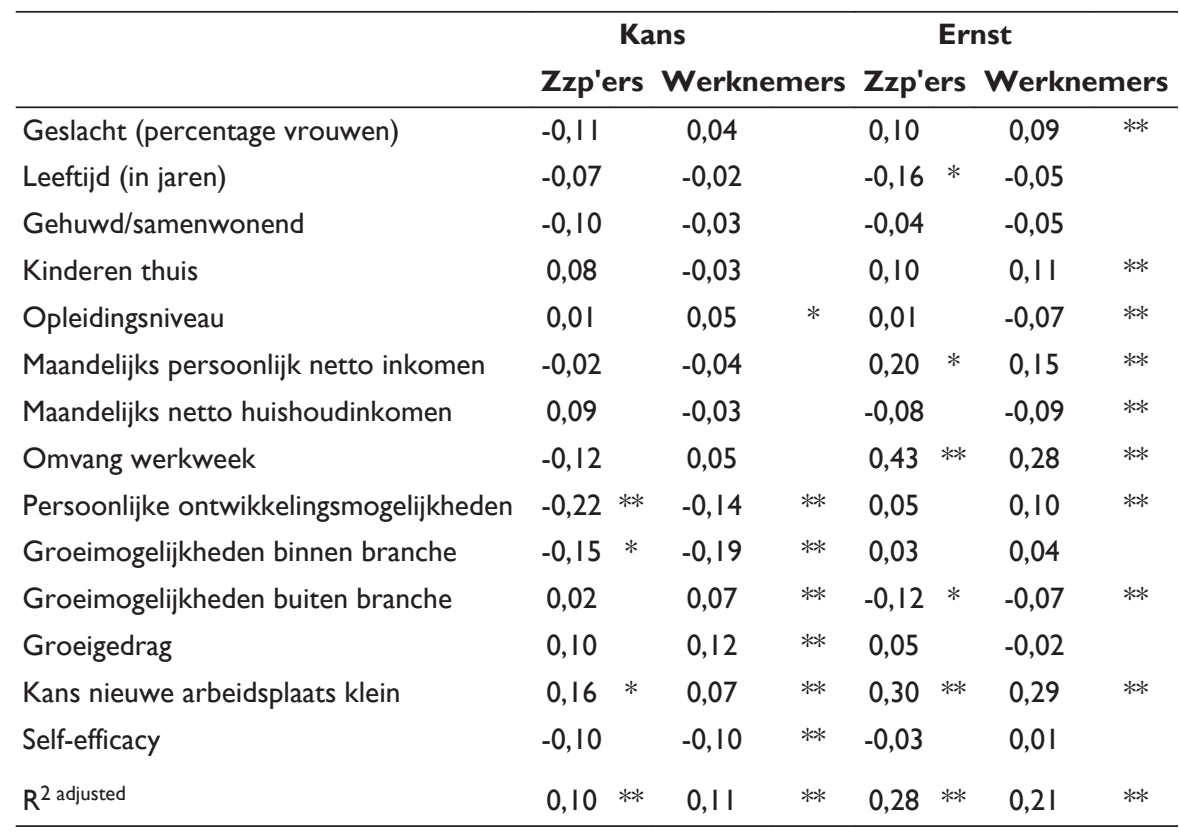

*) Significantieniveaus: $*=p<0,05$; $* *=p<0,0$ I

Uit de analyses blijkt dat zzp'ers menen een grotere kans te hebben om hun bedrijf te verliezen naarmate zij minder persoonlijke ontwikkelingsmogelijkheden en groeimogelijkheden binnen de branche zien en zij de kans op een nieuwe arbeidsplaats klein achten. Werknemers met een vaste baan denken een grotere 
kans te hebben om hun baan te verliezen naarmate zij een hogere opleiding hebben, minder persoonlijke ontwikkelingsmogelijkheden zien, minder groeimogelijkheden binnen de branche, maar wel buiten de branche zien, meer solliciteren naar een andere baan of functie (groeigedrag), een kleinere kans menen te hebben op een nieuwe arbeidsplaats en zij minder vertrouwen hebben in hun eigen kunnen (self-efficacy).

De mate waarin zzp'ers ervaren dat het verlies van hun bedrijf ernstige gevolgen heeft, neemt toe naarmate zzp'ers jong zijn, een hoger persoonlijk netto-inkomen hebben en meer uren per week werken. Bovendien ervaren zzp'ers ernstiger gevolgen van het verlies van hun bedrijf als zij minder groeimogelijkheden buiten de branche zien en de kans op een nieuwe arbeidsplaats klein achten. Bij werknemers met een vast dienstverband wordt het verlies van de baan als ernstiger ervaren door vrouwen en werknemers met de zorg voor kinderen, een laag opleidingsniveau, een hoog persoonlijk inkomen, een laag gezinsinkomen, meer werkuren per week, meer persoonlijke ontwikkelingsmogelijkheden, minder groeimogelijkheden buiten de branche en een als klein ingeschatte kans op een nieuwe arbeidsplaats.

\section{Gevolgen van onzekerheid over de arbeidsplaats}

De tabellen 3 en 4 geven de uitkomsten van meervoudige 3-weg variantieanalyses met de vijf gevolgen van arbeidsplaatsonzekerheid als afhankelijke variabelen. De drie onafhankelijke variabelen zijn: (1) de aard van de arbeidsrelatie (groep: zzp'ers versus werknemers), (2) de waargenomen mate van self-efficacy en (3) de waargenomen kans op verlies van bedrijf of baan of de ingeschatte ernst van het verlies van de baan. Self-efficacy is ingedeeld in $50 \%$ respondenten met een lage en $50 \%$ van de respondenten met een hoge score. De geschatte kans op het verlies van de arbeidsplaats is verdeeld in respondenten die de categorieën 'zeer groot' of 'groot' hebben aangekruist versus de respondenten die 'redelijk', 'klein' en 'zeer klein' aankruisten. De ervaren ernst van het verlies van de arbeidsplaats is verdeeld in respondenten die de categorieën 'zeer ernstig' of 'ernstig' hebben aangekruist versus de respondenten die 'vervelend, maar geen drama', 'niet ernstig' en 'maakt niets uit' aankruisten. We bespreken eerst de analyses voor de kans op het verlies van de arbeidsplaats en beginnen met de hoofdeffecten, daarna volgen de interactie-effecten. 
Tabel 3 Resultaten van 3-weg variantieanalyses bij (1) zzp'ers en werknemers, (2) hoog en laag op self-efficacy en (3) hoog en laag op arbeidsplaatsonzekerheid (kans op en ernst van het verlies van de arbeidsplaats)

\begin{tabular}{|c|c|c|c|c|c|c|}
\hline \multirow{2}{*}{\multicolumn{2}{|c|}{$\begin{array}{l}\text { Kans op verlies arbeids- } \\
\text { plaats klein/groot }\end{array}$}} & \multirow{3}{*}{$\begin{array}{l}\text { Self-effi- } \\
\text { cacy } \\
\text { Laag }\end{array}$} & \multicolumn{2}{|c|}{ Zzp'ers } & \multicolumn{2}{|c|}{ Werknemers } \\
\hline & & & \multirow{2}{*}{$\begin{array}{l}\text { Klein } \\
2,6 \%\end{array}$} & \multirow{2}{*}{$\begin{array}{l}\text { Groot } \\
2,8 \%\end{array}$} & \multirow{2}{*}{$\begin{array}{l}\text { Klein } \\
4,1 \%\end{array}$} & \multirow{2}{*}{$\begin{array}{l}\text { Groot } \\
14,7 \%\end{array}$} \\
\hline- & Verzuimpercentage & & & & & \\
\hline & & Hoog & $4,3 \%$ & $6,0 \%$ & $4,0 \%$ & $9,4 \%$ \\
\hline \multirow[t]{2}{*}{ - } & Presenteïsmepercentage & Laag & $8,1 \%$ & $6,1 \%$ & $5,9 \%$ & $7,3 \%$ \\
\hline & & Hoog & $4,9 \%$ & $10,4 \%$ & $4,6 \%$ & $9,3 \%$ \\
\hline \multirow[t]{2}{*}{ - } & Ervaren gezondheid goed & Laag & 0,60 & 0,56 & 0,59 & 0,52 \\
\hline & & Hoog & 0,66 & 0,56 & 0,67 & 0,45 \\
\hline \multirow[t]{2}{*}{-} & Werk-thuis interferentie & Laag & 0,39 & 0,38 & 0,29 & 0,36 \\
\hline & & Hoog & 0,31 & 0,35 & 0,27 & 0,39 \\
\hline- & Werktevredenheid & Laag & 0,78 & 0,61 & 0,72 & 0,61 \\
\hline & & Hoog & 0,82 & 0,74 & 0,75 & 0,61 \\
\hline \multirow[t]{2}{*}{ - } & Aantal respondenten & Laag & 91 & 111 & 229 & 52 \\
\hline & & Hoog & 27 & 22 & 201 & 20 \\
\hline \multicolumn{2}{|c|}{$\begin{array}{l}\text { Ernst verlies arbeidsplaats } \\
\text { (niet ernstig/ernstig) }\end{array}$} & $\begin{array}{l}\text { Self-effi- } \\
\text { cacy }\end{array}$ & $\begin{array}{l}\text { Niet ern- } \\
\text { stig }\end{array}$ & Ernstig & $\begin{array}{l}\text { Niet ern- } \\
\text { stig }\end{array}$ & Ernstig \\
\hline \multirow[t]{2}{*}{-} & Verzuimpercentage & Laag & $2,6 \%$ & $2,7 \%$ & $3,2 \%$ & $9,0 \%$ \\
\hline & & hoog & $3,7 \%$ & $5,8 \%$ & $3,0 \%$ & $5,8 \%$ \\
\hline \multirow[t]{2}{*}{ - } & Presenteïsmepercentage & Laag & $6,2 \%$ & $9,5 \%$ & $5,1 \%$ & $7,2 \%$ \\
\hline & & hoog & $4,8 \%$ & $7,3 \%$ & $5,2 \%$ & $4,8 \%$ \\
\hline \multirow[t]{2}{*}{ - } & Ervaren gezondheid goed & Laag & 0,57 & 0,61 & 0,60 & 0,57 \\
\hline & & hoog & 0,64 & 0,64 & 0,64 & 0,65 \\
\hline \multirow[t]{2}{*}{ - } & Werk-thuis interferentie & Laag & 0,37 & 0,42 & 0,28 & 0,33 \\
\hline & & hoog & 0,27 & 0,38 & 0,27 & 0,29 \\
\hline \multirow[t]{2}{*}{-} & Werktevredenheid & Laag & 0,71 & 0,77 & 0,71 & 0,69 \\
\hline & & hoog & 0,80 & 0,81 & 0,73 & 0,75 \\
\hline \multirow{2}{*}{\multicolumn{2}{|c|}{ Aantal respondenten }} & Laag & 66 & 52 & 143 & 138 \\
\hline & & hoog & 77 & 56 & 104 & 117 \\
\hline
\end{tabular}

De vergelijking tussen zzp'ers en werknemers (hoofdeffect: groep) wat betreft hun welbevinden en gezondheid pakt in tabel 3 iets anders uit dan in tabel 1 . Zzp'ers hebben in tabel 3 een significant lager ziekteverzuim dan werknemers. In tabel 1 is dat niet het geval. Het significante verschil in de mate van werk-thuis interferentie in tabel 1 is niet significant in tabel 3. Zzp'ers zijn in beide tabellen significant wel meer tevreden met hun werk dan werknemers. Uit tabellen 3 en 4 blijkt verder dat de mate van self-efficacy maar één keer samenhangt met de vijf 
Tabel $4 \quad F-$ en P-waarden bij de variantieanalyses van tabel 3

\begin{tabular}{|c|c|c|c|c|c|c|c|c|}
\hline \multicolumn{2}{|c|}{ Kans op verlies arbeidsplaats } & \multirow{2}{*}{$\begin{array}{l}\text { Groep } \\
\text { F } 7,26\end{array}$} & \multirow{2}{*}{$\begin{array}{l}\text { Self-efficacy } \\
0,01\end{array}$} & \multirow{2}{*}{$\begin{array}{l}\text { Kans } \\
8,4 I\end{array}$} & \multirow{2}{*}{$\begin{array}{l}\mathbf{G x S} \\
2,82\end{array}$} & \multirow{2}{*}{$\begin{array}{l}\text { GxK } \\
5,24\end{array}$} & \multirow{2}{*}{$\begin{array}{l}\text { SxK } \\
0,34\end{array}$} & \multirow{2}{*}{$\begin{array}{l}\text { GxSxK } \\
1,19\end{array}$} \\
\hline- & Verzuimpercentage & & & & & & & \\
\hline & & P 0,007 & $0,94 I$ & 0,004 & 0,093 & 0,022 & 0,560 & 0,275 \\
\hline \multirow[t]{2}{*}{-} & Presenteïsmepercentage & $\mathrm{F} 0,19$ & 0,10 & 2,75 & 0,00 & 0,21 & 3,47 & 0,51 \\
\hline & & $P 0,666$ & 0,749 & 0,097 & 0,946 & 0,645 & 0,063 & 0,476 \\
\hline \multirow[t]{2}{*}{-} & Ervaren gezondheid goed & F 2,13 & 0,47 & 24,21 & 0,50 & 2,96 & 5,55 & 1,05 \\
\hline & & $P 0,145$ & 0,495 & 0,000 & 0,479 & 0,086 & 0,019 & 0,307 \\
\hline \multirow[t]{2}{*}{-} & Werk-thuis interferentie & F I,97 & $\mathrm{I}, 24$ & 5,34 & 2,04 & 3,08 & 1,32 & 0,01 \\
\hline & & P 0,161 & 0,267 & 0,021 & 0,154 & 0,079 & 0,25 I & 0,911 \\
\hline \multirow[t]{2}{*}{-} & Werktevredenheid & F 7,95 & 5,10 & 31,99 & 2,20 & 0,02 & 0,61 & $\mathrm{I}, 56$ \\
\hline & & P 0,005 & 0,024 & 0,000 & 0,138 & 0,877 & 0,435 & 0,212 \\
\hline \multicolumn{2}{|c|}{ Ernst verlies arbeidsplaats } & Groep & Self-efficacy & Ernst & GxS & GxE & SxE & GxSxE \\
\hline \multirow[t]{2}{*}{-} & Verzuimpercentage & F I,93 & 0,03 & 5,61 & 2,80 & 1,89 & 0,06 & $\mathrm{I}, \mathrm{I} 8$ \\
\hline & & $P 0,165$ & 0,870 & 0,018 & 0,095 & 0,170 & 0,808 & 0,277 \\
\hline \multirow[t]{2}{*}{-} & Presenteïsmepercentage & F I,62 & 1,91 & 3,22 & 0,10 & 0,90 & 0,61 & 0,19 \\
\hline & & P 0,203 & 0,168 & 0,073 & 0,755 & 0,342 & 0,436 & 0,667 \\
\hline \multirow[t]{2}{*}{-} & Ervaren gezondheid goed & $\mathrm{F} 0,00$ & 12,94 & 0,09 & 0,23 & 0,88 & 0,07 & 1,22 \\
\hline & & P 0,978 & 0,000 & 0,763 & 0,633 & 0,349 & 0,789 & 0,269 \\
\hline \multirow[t]{2}{*}{-} & Werk-thuis interferentie & F 16,74 & 7,44 & 12,05 & $\mathrm{I}, 73$ & I,7I & 0,30 & ।,35 \\
\hline & & P 0,000 & 0,007 & 0,001 & 0,189 & 0,192 & 0,585 & 0,245 \\
\hline \multirow[t]{2}{*}{-} & Werktevredenheid & F 10,35 & 8,46 & $\mathrm{I}, 30$ & 0,53 & $\mathrm{I}, 0 \mathrm{I}$ & 0,02 & 2,10 \\
\hline & & $P 0,001$ & 0,004 & 0,254 & 0,468 & 0,315 & 0,892 & 0,148 \\
\hline
\end{tabular}

welzijns- en gezondheidskenmerken (hoofdeffect: self-efficacy). Respondenten met een hoog vertrouwen in eigen kunnen (self-efficacy) zijn significant meer tevreden over hun werk. Daarnaast tonen deze tabellen dat - zowel bij werknemers als bij zzp'ers - een grotere ervaren kans op verlies van de arbeidsplaats samenhangt met meer ziekteverzuim, meer presenteïsme, een ongunstiger oordeel over de eigen gezondheid, meer werk-thuis interferentie, minder werktevredenheid (hoofdeffect: kans).

Er zijn in het bovenste deel van de tabellen 3 en 4 geen significante 3-weg interacties gevonden, maar wel zes significante 2 -weg interacties (als ook het 10\%-kansniveau wordt meegenomen). We bespreken ze hier per type 2-weg effect. Als het gaat om groep en self-efficacy (interactie-effect: $\mathrm{GxS}$ ), dan blijkt dat het verzuimpercentage hoog is bij zzp'ers die hoog scoren op self-efficacy en bij werknemers die laag scoren op self-efficacy $(\mathrm{p}=0,093)$. Bij de andere vier effectmaten is geen significante interactie gevonden. Er zijn drie significante interacties gevonden in de kolom GxK. Zzp'ers die de kans op het verlies op hun bedrijf als klein inschatten, hebben een laag verzuimpercentage $(p=0,022)$. Werknemers die de kans op het verlies van hun baan als groot inschatten, hebben een ongunstig oordeel over hun eigen gezondheid $(p=0,086)$. Werknemers die de kans als klein inschatten 
hebben weinig werk-thuis interferentie $(\mathrm{p}=0,079)$. In de kolom SxK zijn twee significante interactie-effecten gevonden. Werknemers én zzp'ers met een hoge mate van self-efficacy en een hoge ingeschatte kans op het verlies van de arbeidsplaats werken vaker ziek door $(p=0,063)$. Werknemers én zzp'ers met geringe ingeschatte kans op het verlies van hun arbeidsplaats en een hoge mate van selfefficacy ervaren een goede gezondheid ( $p=0,019)$.

Wat betreft het hoofdeffect van groep zijn de uitkomsten voor de verschillen in het onderste deel van tabel 3 en 4 dezelfde als die in tabel 1 . Zzp'ers ervaren meer werk-thuis interferentie $(\mathrm{p}=0,000)$ en zijn meer tevreden met hun werk dan vaste werknemers $(p=0,001)$. Er is dus geen invloed van de overige variabelen op de aanwezigheid van deze verschillen. Wat betreft het hoofdeffect van self-efficacy blijkt dat respondenten met een hoge mate van self-efficacy hun gezondheid gunstiger beoordelen ( $p=0,000)$, minder last hebben van werk-thuis interferentie $(\mathrm{p}=0,007)$ en meer tevreden zijn met het werk dat ze doen $(\mathrm{p}=0,004)$. Ook vinden we drie hoofdeffecten van de ernst van het verlies van de arbeidsplaats. Personen die het verlies van het werk als ernstig ervaren, hebben een hoger verzuimpercentage $(p=0,018)$, een hoger presenteïsmepercentage $(p=0,073)$ en meer werk-thuis interferentie $(\mathrm{p}=0,001)$.

In de twee onderste delen van de tabellen 3 en 4 zijn geen significante 3-weg interacties aanwezig en één significante 2-weg interactie: Het ziekteverzuim van werknemers met een vaste aanstelling is hoger als zij minder vertrouwen hebben in eigen kunnen en bij zzp'ers is het dan juist lager ( $p=0,095)$.

\section{Discussie}

Het onderzoek laat zien dat zzp'ers vrijwel evenveel arbeidsplaatsonzekerheid ervaren als werknemers met een vaste baan. Dat wil zeggen dat zzp'ers een kleine, maar wel iets grotere kans waarnemen op verlies van hun bedrijf en dat ze de gevolgen als even ernstig ervaren als werknemers het verlies van de baan ervaren. Dit lijkt overeen te komen met de bevindingen van Smulders en Evers (2000). Zij vonden dat zelfstandigen in vergelijking met tijdelijk aangestelde werknemers meer baanzekerheid ervaren, maar minder baanzekerheid hebben dan vaste werknemers. Hun onderzoek betrof echter zelfstandigen met en zonder personeel, dus de onderzochte groep is niet geheel vergelijkbaar.

Zzp'ers blijken ten dele te verschillen van werknemers met een vast dienstverband in de determinanten van de waargenomen kans op verlies van werk en in de determinanten van de ervaren ernst van het verlies van werk. Maar voor een deel komen de determinanten tussen beide groepen ook overeen. Zo ervaren zzp'ers en werknemers een grotere kans op verlies van de arbeidsplaats, als zij de kans op een nieuwe arbeidsplaats klein achten, zij zich minder kunnen ontwikkelen in het bedrijf en zij minder groeimogelijkheden zien binnen de branche of het bedrijf. En wat betreft de ervaren ernst van de gevolgen van verlies van de arbeidsplaats, ervaren zzp'ers en vaste werknemers dit in sterkere mate als zij een hoger persoonlijk netto-inkomen hebben en meer uren per week werken. Bovendien ervaren zzp'ers en vaste werknemers ernstiger gevolgen van het verlies van hun 
bedrijf als zij de kans klein achten op een andere arbeidsplaats en als zij minder groeimogelijkheden buiten hun branche of bedrijf zien. Kortom, er is overlap in de determinanten van arbeidsplaatsonzekerheid tussen zzp'ers en werknemers Objectieve kenmerken als geslacht, leeftijd, zorg voor kinderen, persoonlijk nettoinkomen blijken zowel voor zzp'ers als voor werknemers met een vast dienstverband nauwelijks samen te gaan met de kans die men ziet op het verlies van de arbeidsplaats. Dit bevestigt wat al eerder was gevonden in onderzoek onder werknemers. Namelijk dat het voor de ervaren kans op verlies van werk er minder om gaat dat dergelijke objectieve factoren van toepassing zijn en meer of men denkt dat deze nadelig voor hen zijn (Van Vuuren, 1990; Van Vuuren et al., 1991a). Wat betreft het verband met de ervaren ernst van de gevolgen van mogelijk verlies van de arbeidsplaats wijzen deze objectieve factoren meer op de feitelijke situatie bijvoorbeeld een hoger persoonlijk inkomen, en dan is er ook meer te verliezen.

Zzp'ers komen ook voor een deel overeen met werknemers in hun reactie op arbeidsplaatsonzekerheid. Zowel zzp'ers als werknemers die een grotere kans zien om hun arbeidsplaats te verliezen, hebben een hoger ziekteverzuim, een ongunstiger oordeel over de eigen gezondheid, meer werk-thuis interferentie, minder werktevredenheid en werken vaker ziek door. Ook hebben zowel zzp'ers als werknemers met een vast dienstverband die het verlies van het werk ernstig vinden een hoger ziekteverzuim, meer werk-thuis interferentie en werken ze meer ziek door. Daarnaast verschillen zzp'ers ten dele ook van werknemers in de mate waarin zij reageren op de kans om hun werk te verliezen, maar verschillen zij niet van elkaar in hun reactie op de ernst van het verlies. Hoewel beide groepen last hebben van arbeidsplaatsonzekerheid, gaan werknemers daar wat meer onder gebukt in die zin dat zij dan veel meer gaan verzuimen, een slechtere gezondheid ervaren en een grotere werk-thuis interferentie dan zzp'ers als zij vrezen hun arbeidsplaats te verliezen.

Het is te begrijpen dat de door ons onderzochte zzp'ers niet veel verschillen van werknemers in hun reacties, omdat zij ook vrijwel in gelijke mate menen dat er kleine kans is om hun arbeidsplaats te verliezen en in even grote mate ernstige gevolgen van een eventueel verlies ervaren. Dat geldt niet voor flexkrachten zoals tijdelijke werknemers en uitzendkrachten. Die ervaren een beduidend hogere kans om ontslagen te worden dan vaste krachten, maar verwachten significant minder ernstige gevolgen daarvan (Klandermans et al., 2010). Wij denken dat dit een mogelijke verklaring is waarom flexkrachten minder negatieve welzijns- en gezondheidseffecten ervaren van arbeidsplaatsonzekerheid dan vaste werknemers (De Cuyper \& De Witte, 2005, 2006, 2007, 2008; Klandermans et al., 2010; Klein Hesselink \& Van Vuuren, 1999; Parker, Griffin, Sprigg \& Wall, 2002; Pearce, 1998.)

In eerder onderzoek (Klandermans et al., 2010) vonden we: hoe flexibeler de arbeidsrelatie, hoe groter de kans wordt ervaren om de arbeidsplaats te verliezen, en hoe minder men de gevolgen vreest van het verlies van de arbeidsplaats. Maar ook: hoe flexibeler de arbeidsrelatie, hoe geringer men de gevolgen als ernstig ervaart, hoe minder men ook last heeft van deze dreiging en hoe geringer het verband tussen de kans op verlies van werk en de gevolgen voor welzijns- en gezondheidskenmerken. We zien deze verschillen echter slechts beperkt terug als we de 
zzp'ers vergelijken met de werknemers met een vast dienstverband. Zzp'ers lijken qua arbeidsplaatszekerheid meer op de vaste werknemers dan we hadden verwacht: Beide groepen ervaren vrijwel evenveel arbeidsplaatsonzekerheid, hebben grotendeels dezelfde determinanten van arbeidsplaatsonzekerheid en vertonen vrijwel dezelfde reacties op arbeidsplaatsonzekerheid. Werknemers vertonen alleen meer ziekteverzuim dan zzp'ers in reactie op arbeidsplaatsonzekerheid. Zzp'ers lijken dus wat betreft arbeidsplaatsonzekerheid minder op flexkrachten zoals tijdelijke werknemers, oproepkrachten en uitzendkrachten, maar meer op werknemers met een vaste aanstelling. De bijna even grote mate waarin zzp'ers en vaste werknemers arbeidsplaatsonzekerheid ervaren, onderschrijft de stelling van Dekker en Kösters (2010) dat de werkzekerheid van zzp'ers niet noodzakelijk lager hoeft te zijn dan die van vaste werknemers.

Zzp'ers en werknemers verschillen niet wat betreft de bufferende werking van self-efficacy. Bij werknemers is een dergelijke relatie door Sverke et al. (2004) en Schreurs et al. (2010) niet gevonden, en ook bij zzp'ers zien we niet dat naarmate self-efficacy toeneemt, de gevolgen van arbeidsplaatsonzekerheid in termen van welzijns- en gezondheidskenmerken afnemen. Wij sluiten ons daarom aan bij König et al. (2010) die zich zelfs afvragen of self-efficacy in het geval van arbeidsplaatsonzekerheid wel een hulpbron kan zijn die de dreiging van het verlies van de arbeidsplaats zou kunnen compenseren.

\section{Enkele kanttekeningen}

Het onderzoek kent verschillende beperkingen. In de eerste plaats zijn de groepen klein. Daardoor zijn verschillen niet snel statistisch significant en zullen verschillen zich minder snel kunnen uitmiddelen. In de tweede plaats maakt de crosssectionele opzet van de studie het niet mogelijk conclusies te trekken over causale verbanden. We spreken over determinanten en effecten, maar sommige determinanten zouden wellicht een reactie kunnen zijn en andersom. In de derde plaats is het veldwerk van het onderzoek gehouden in de laatste maanden van 2006 toen de economische situatie nog optimaal gunstig was voor het verkrijgen van opdrachten. In economisch ongunstige tijden kunnen determinanten en effecten anders zijn. Met een mogelijke opleving van de economie en het te verwachten tekort aan personeel, zal dit argument in de toekomst echter minder gaan spelen. In de vierde en laatste plaats is het vergelijken van zzp'ers en werknemers op basis van vele 1 -item variabelen, die soms ook nog verschillend zijn geformuleerd, een minder optimale methode.

Uit het voorgaande blijkt dat de overeenkomsten tussen zzp'ers en werknemers met een vast dienstverband groter zijn dan de verschillen. De vraag kan dan ook gesteld worden waarom zelfstandigen zonder personeel zoveel lijken op werknemers met een aanstelling voor onbepaalde tijd. Daar is een veelheid van redenen voor aan te geven, die grotendeels te maken hebben met de zekerheid die de zzp'ers ongemerkt hebben. We noemen er zeven. In de eerste plaats blijkt dat veel zzp'ers uit gezinnen komen met meerdere inkomens (Klein Hesselink e.a., 2008). Bij veel zzp'ers werkt de partner en beide inkomens garanderen meer inkomens- 
zekerheid dan als de zzp'er alleen verantwoordelijk zou zijn voor het gezinsinkomen. In de tweede plaats blijkt dat zzp'ers per jaar voor minimaal drie opdrachtgevers moeten werken voor een minimum van 1225 uren per jaar om een verklaring arbeidsrelatie te krijgen van de Belastingdienst. Daarmee heeft deze belastingregel in feite een zekerheidsverhogend effect op het inkomen. Zzp'ers die niet in aanmerking komen voor de juiste verklaring arbeidsrelatie (Resultaat uit Overige Werkzaamheden of Loon) zullen al snel afvallen als kandidaat voor opdrachtgevers en hun heil moeten zoeken in bijvoorbeeld uitzendbanen en/of een combinatie van tijdelijke en/of parttime banen. In de derde plaats werken veel zzp'ers soms tijdelijk voor een werkgever of een uitzendbureau, of ze doen dat naast hun zzp-schap. Dat geldt ook voor degenen die wel de juiste verklaring arbeidsrelatie hebben (Werk Uit Onderneming, of Directeur/ Grootaandeelhouder). In de vierde plaats is er in Nederland nooit sprake van het volledig ontbreken van sociale zekerheid. Uiteindelijk heeft iedereen recht op bijstand. Dat betekent mogelijk dat men een deel van het inkomen en privébezittingen moet opgeven, maar niet dat men volledig in de armoede belandt. In de vijfde plaats lopen zzp'ers niet de grote financiële risico's die veel ondernemers met een eigen onderneming maar zonder personeel in dienst, wel lopen. Zzp'ers hebben doorgaans niet de verantwoordelijkheid voor een grote kapitaalsinvestering in bijvoorbeeld een agrarische onderneming of een winkelpand. In de zesde plaats hebben veel zzp'ers verzekeringen afgesloten om bij ziekte of werkloosheid de inkomensgevolgen te verminderen. Dat zijn vaak 'dure' verzekeringen (net als bij werknemers overigens), maar die garanderen wel dat men een stuk minder inkomensrisico loopt. In de zevende plaats komen er steeds meer samenwerkingsverbanden waardoor zzp'ers tijdelijk in netwerkorganisaties ook voor grotere klussen ingezet kunnen worden. Daarmee wordt de kans op het behoud van opdrachten verhoogd en de arbeidsplaatsonzekerheid minder.

\section{Literatuur}

Ashford, S.J., Lee, C. \& Bobko, P. (1989). Content, causes, and consequences of job insecurity: A theory-based measure and substantive test. Academy of Management Journal, $32,803-829$.

Bandura, A. (1997). Self-efficacy: The exercise of control. New York: Freeman.

Bandura, A. (1998). Health promotion from the perspective of social cognitive theory. Psychology and Health, 13, 623-649.

Baron, R.M. \& Kenny, D.A. (1986). The Moderator-Mediator Variable Distinction in Social Psychological Research: Conceptual, Strategic, and Statistical Considerations. Journal of Personality and Social Psychology, 51, 6, 1173-1182.

Camden, C. (2008). 10 personality traits of a highly effective independent consultant, Blog Techrepublic, http://www.techrepublic.com/blog/project-management/10-personalitytraits-of-a-highly-effective-independent-consultant/212

CBS (2008). Zelfstandige zonder personeel 1, 30-09-2008, http://www.cbs.nl/nl-NL/ menu/methoden/toelichtingen/alfabet/z/zzp.htm

Cheng, G. \& Chan, D. (2008). Who suffers more from job insecurity? A meta-analytic review. Applied Psychology: An International Review, 57(2), 272-303. 
Dasselaar, A. (2011). Handboek voor de ZZP'er 2011-2012 (3e druk). Culemborg: Van Duuren Media.

De Cuyper, N. \& De Witte, H. (2005). Job Insecurity: mediator or moderator of the relationship between type of contract and various outcomes? Journal of Industrial Psychology, 31, 79-86.

De Cuyper, N. \& De Witte, H. (2006). The impact of job insecurity and contract type on attitudes, well-being and behavioural reports: A psychological contract perspective. Journal of Occupational Psychology, 79, 395-409.

De Cuyper, N. \& De Witte, H. (2007). Job Insecurity in temporary versus permanent workers: Associations with attitudes, well-being, and behaviour. Work and Stress, 21(1), 65-84.

De Cuyper, N. \& De Witte, H. (2008). Job Insecurity and Employability among Temporary Workers: A Theoretical Approach based on the Psychological Contract. In K. Näswall, J. Hellgren \& M. Sverke (Eds.), Balancing work and well-being: The individual in the changing work life (pp. 63-88). Cambridge: Cambridge Press.

Dekker, R. \& Kösters, L. (2010). Zzp'ers in Nederland: de baanzekerheid voorbij? SociaalEconomische Trends, 2010-4, CBS.

De Witte, H. (2005). Job insecurity: Review of the international literature on definitions, prevalence, antecedents and consequences. South African Journal of Industrial Psychology31(4), 1-6.

De Witte, H. \& Näswall, K. (2003). ‘Objective’ vs. 'Subjective' Job Insecurity: Consequences of Temporary Work for Job Satisfaction and Organizational Commitment in Four European Countries. Economic and Industrial Democracy, 24, 149-188.

Geurts, S.A.E. \& Demerouti, E. (2003). In M.J. Schabracq, J.A.M. Winnubst \& C.L. Cooper, (red.), The Handbook of Work and Health Psychology. West Sussex: John Wiley \& Sons.

Greenhalgh, L. \& Rosenblatt, Z. (1984). Job insecurity: Towards conceptual clarity. Academy of Management Review, 9, 438-448.

Gründemann, R.W.M., Smulders, P.G.W. \& De Winter, C.R. (1993). VAG. Vragenlijst Arbeid en Gezondheid. Handleiding. Lisse: Swets Test Services.

Hartley, J., Jacobson, D., Klandermans, B. \& Van Vuuren, T. (1991). Job Insecurity. Coping with Jobs at Risk. Londen: Sage.

Hellgren, J., Sverke, M. \& Isaksson, K. (1999). A two-dimensional approach to job insecurity: consequences for employee attitudes and well-being. European Journal of Work and Organizational Psychology, 8 (2), 179-195.

Hilbers, P. (2010). Kennismemo 10 02. Groei van de flexibele arbeid en de gevolgen voor het beroep op WW (22 april 2010). Amsterdam: Kenniscentrum UWV.

Jacobson, D. (1985). Determinants of 'Jobs at Risk' (JAR) behavior. Paper presented at the West European Conference on the Psychology of Work and Organization in Aachen, Federal Republic of Germany.

Jacobson, D. (1991). The conceptual approach to Job Insecurity. In J. Hartley, D. Jacobson, B. Klandermans \& T. van Vuuren (Eds.), Job Insecurity. Coping with Jobs at Risk (pp. 23-39). Londen: Sage.

Johns, G. (2010). Presenteeism in the Workplace: A review and research agenda. Journal of Organizational Behavior, 31, 519-542.

Kinnunen, U., Feldt, T. \& Mauno, S. (2003). Job insecurity and self-esteem: evidence from cross-lagged relations in a 1-year longitudinal sample. Personality and Individual Differences 35, 3, 617-632.

Kinnunen, U. \& Natti, J. (1994). Job Insecurity in Finland: Antecedents and consequences. European Journal of Work and Organizational Psychology, 4, 297-321. 
Klandermans, B. \& Van Vuuren, T. (1999). Job insecurity: Introduction. European Journal of Work and Organizational Psychology, 8, 145-153.

Klandermans, B., Van Vuuren, T. \& D. Jacobson, (1991). Employees and Job Insecurity. In J. Hartley, D. Jacobson, B. Klandermans \& T. van Vuuren, (Eds.), Job Insecurity.Coping with Jobs at Risk (pp. 40-64). Londen: Sage.

Klandermans, B., Klein Hesselink, J. \& Van Vuuren, T. (2010). Employment status and job insecurity: On the subjective appraisal of an objective status. Economic and Industrial Democracy, 31(4), 557-577.

Klein Hesselink, D.J. \& Van Vuuren, T. (1999). Job flexibility and job insecurity: The Dutch case. European Journal of Work and Organizational Psychology, 8, 273-294.

Klein Hesselink, J., Kooij-de Bode, H. \& Koppenrade, V. (2008). Wie zijn de overige flexwerkers en hoe gaan zij om met het risico van ziekte. Hoofddorp: TNO Kwaliteit van Leven.

König, C.J., Debus, M.E., Häusler, S., Lendenmann, N. \& Kleinmann, M. (2010). Examining occupational self-efficacy, work locus of control and communication as moderators of the job insecurity-job performance relationship. Economic and Industrial Democracy, 31(2), 231-247.

Kösters, L. (2010). In het derde kwartaal van 2010 opnieuw meer zelfstandigen zonder personeel. CBS Webmagazine, 8 december 2010.

Kösters, L. \& Dekker, R. (2010). Meer zelfstandigen zonder personeel. Sociaal Bestek, 6-2010, p. 26.

McKeown, T., Connelly, C.E. \& Gallagher, D.G. (2009). Working without an employer:establishing a model of Independent contractors' well-being. Paper presented at the International Industrial Relations Association (IIRA) 15th World Congress in Sydney, Australia, 24-27 August, 2009. www.ilera-online.org/15thworldcongress/files/.../ Thur_P5_MCKEOWN.pdf

McKeown, T. \& Hanley, G. (2009). Challenges and changes in the contractor workforce. Asia Pacific Journal of Human Resources, 47, 295-317.

Parker, S.K., Griffin, M.A., Sprigg, C.A. \& Wall, T.A. (2002). Effect of temporary contracts on perceived work characteristics and job strain: A longitudinal study. Personnel Psychology, 55, 689-717.

Pearce, J. (1993). Toward an organizational behavior of contract laborers: Their psychological involvement and effects on employee co-workers. Academy of Management Journal, 36(5), 1082-1096.

Schreurs, B., Van Emmerik, H., Notelaers, G. \& De Witte, H. (2010). Job insecurity and employee health: The buffering potential of job control and job self-efficacy. Work \& Stress, 24, 56-72.

Schwarzer, R. \& Jeruzalem, M. (1995). Generalized self-efficacy scale. In J. Weinman, S. Wright \& M. Johnston (Eds.), Measures in health psychology: A user's portfolio. Causal and control beliefs (pp. 35-37). Windsor, UK: NFER-NELSON.

Smulders, P., Andries, F. \& Otten, F. (2001). TNO Arbeidssituatie Survey: Eerste meting (2000): opzet en kwaliteitsbeoordeling. Hoofddorp: TNO Arbeid.

Sverke, M., Hellgren, J. \& Näswall, K. (2002). No security: A meta-analysis and review of job insecurity and its consequences. Journal of Occupational Health Psychology, 7, 242-264.

Sverke, M, Hellgren, J., Näswall, K., Chirumbolo, A., De Witte, H. \& Goslinga, S. (2004). Job Insecurity and Union Membership: European Unions in the Wake of Flexible Production. Brussel: PIE-Peter Lang.

Taal, G. (2010). Helft bedrijfsleven gebruikt zelfstandigen zonder personeel. CBS Webmagazine, 8 december 2010. 
Van den Boomen, T. (2011). ZZP 2011. Handboek voor zelfstandigen. Amsterdam: Uitgeverij Nieuwezijds.

Van den Bossche, S., Koppens, L., Granzier, J., De Vroome, E. \& Smulders, P. (2007). Nationale Enquête Arbeidsomstandigheden 2007. Methodologie en globale resultaten. Hoofddorp: TNO Kwaliteit van Leven.

Van Hooff, M. (2007). Work-Home Interference in Effort-Recovery Perspective. Dissertation. Nijmegen: Radboud University.

Van Vuuren, T. (1990). Met ontslag bedreigd. Werknemers in onzekerheid over hun arbeidsplaats bij veranderingen in de organisatie. Amsterdam: VU-uitgeverij.

Van Vuuren, T. (1991). Onzekerheid over de arbeidsplaats en het psychisch welbevinden. Directe en indirecte effecten van sociale en psychologische factoren. Gedrag en Gezondheid, 19, 4, 191-204.

Van Vuuren, T., Klandermans, B., Jacobson, D. \& Hartley, J. (1991a). Predicting Employees' Perceptions of Job Insecurity. In J. Hartley, D. Jacobson, B. Klandermans \& T. van Vuuren, Job insecurity: Coping with jobs at risk (pp. 65-78). Londen: Sage.

Van Vuuren, T., Klandermans, B., Jacobson, D. \& Hartley, J. (1991b). Employees' Reactions to Job Insecurity. In J. Hartley, D. Jacobson, B. Klandermans \& T. van Vuuren, Job insecurity: Coping with jobs at risk (pp. 79-104). Londen: Sage.

Wilthagen, T. \& Tros, F. (2004). The concept of 'flexicurity': a new approach to regulating employment and labour markets. Transfer: European Review of Labour and Research, 10, 2, 166-186. 